\title{
Менеджмент пацієнта з варикозним розширенням вен нижніх кінцівок
}

\author{
О.М. Волошин, О.В. Суздаленко, В.О. Губка, С.М. Мачуський, В.Д. Павліченко, О.Г. Попова, С.Т. Расул-заде \\ Судинний центр «АнгіоЛайф», Запоріжжя, Україна
}

Анотація. Опубліковано велику кількість рекомендацій з лікування хронічних захворювань вен, зокрема хронічної венозної недостатності, але в жодному з цих документів не відображено повний «шлях» пацієнта від етапу первинного візиту (діагностики) до вибору оптимального варіанта лікування. Тому створення протоколу, який враховував би сучасні доведено ефективні підходи до діагностики та лікування, а також індивідуальні особливості пацієнта, $є$ актуальним завданням. Мета публікації: створення практично орієнтованої інструкції з діагностики, комплексного лікування та профілактики хронічної венозної недостатності. Менеджмент пацієнта представлено у вигляді набору чітких практичних рекомендацій для судинного хірурга та флеболога. Протокол розроблено на підставі власного практичного досвіду, існуючих протоколів та настанов щодо лікування пацієнтів із хронічною венозною недостатністю. Протокол передбачає чотири етапи комплексу медичних заходів, мета якого - формування чіткої програми подальшого обстеження та лікування хворого. Дотримання всіх рекомендацій, зазначених у протоколі, дає змогу отримати задовільні функціональні та косметичні результати лікування пацієнтів із хронічною венозною недостатністю з мінімальним ризиком рецидиву.

Ключові слова: варикозне розширення вен нижніх кінцівок, хронічна венозна недостатність, алгоритм лікування варикозного розширення вен нижніх кінцівок.

\section{Актуальність проблеми}

Флебологія - одна з медичних спеціальностей, які зазнали найактивнішого розвитку протягом останніх двох десятиліть, оскільки було кардинально переглянуто підходи до діагностики та лікування хронічних захворювань вен нижніх кінцівок (ВНК) [1]. Водночас практичні лікарі продовжують стикатися з труднощами як при діагностиці, так і виборі оптимальної тактики лікування в конкретному клінічному випадку [2]. Опубліковані клінічні рекомендації, розроблені такими авторитетними організаціями, як Європейське товариство васкулярних хірургів (European Society for Vascular Surgery - ESVS), Американський венозний форум (American Venous Forum - AVF), Національний інститут здоров'я і досконалості допомоги (National Institute for Health and Care Excellence - NICE) тощо, $\epsilon$ надзвичайно корисними інструментами, в яких відображено основні аспекти для роботи сучасних флебологів, зокрема найбільш безпечні та ефективні діагностичні тести і лікувальні втручання [3-5], але в жодному з цих документів не відображено повний «шлях» пацієнта від етапу первинного візиту (діагностики) до вибору оптимального варіанта лікування, подальшої реабілітації та вторинної профілактики хронічних захворювань ВНК [6]. Отже, створення протоколу, який враховував би сучасні та доведено ефективні підходи до діагностики та лікування, а також індивідуальні особливості пацієнта (анатомічна будова венозної системи, супутні захворювання, якість життя), дасть змогу флебологам стандартизувати і поліпшити результати лікування та виправдати очікування пацієнтів щодо лікування.

За даними численних рандомізованих досліджень і метааналізів, ендовенозні методи лікування демонструють значні переваги щодо терміну реабілітації та функціональних і косметичних результатів лікування [9, 14]. Вибір оптимальної тактики має ґрунтуватися на комбінації сучасних методик (термальні та нетермальні методи облітерації, склеротерапії, стрипінгу та мініфлебектомії) з урахуванням їх потенційних переваг та недоліків [10]. Таким чином, створення повноцінного протоколу діагностики і лікування хронічних захворювань вен, який можна використовувати в рутинній практиці сучасного лікаря-флеболога, $\epsilon$ актуальним завданням.

\section{Сфера застосування}

Головна сфера застосування протоколу - діяльність хірургів, судинних хірургів і флебологів під час первинного прийому пацієнтів із хронічною венозною недостатністю (ХВН). Запропонований алгоритм дасть змогу практикуючим лікарям стандартизувати і поліпшити результати лікування таких па- цієнтів за декількома напрямами. По-перше, стандартизація диференційної діагностики (своєчасне виявлення неврологічної та кістково-м'язової патології, а також малопоширених причин трофічних виразок) дасть змогу уникнути діагностичних помилок і виправдати сподівання пацієнта щодо проведеного лікування [7]. По-друге, прихильність до рутинної оцінки ключових точок у стандартизованому протоколі ультразвукового дуплексного сканування (УЗДС) дасть змогу виявити джерела рефлюксу, посттромботичні зміни чи зовнішню компресію венозних судин, що $\epsilon$ ключовим завданням на етапі складання плану лікування [8]. По-третє, використання стандартних класифікаторів CEAP (Clinic — клініка, Etiology — етіологія, Anatomy анатомія, Pathogenesis - патогенез) та VCSS (Venous Clinical Severity Score), а також об'єктивної оцінки якості життя пацієнта із ХВН дасть змогу об'єктивно оцінити віддалені результати лікування $[22,23]$.

\section{Нормативна база}

Протокол розроблено та впроваджено в практичну роботу Судинного центру «АнгіоЛайф» (Запоріжжя), основною спеціалізацією якого $\epsilon$ лікування пацієнтів із хронічними захворюваннями венозної системи.

\section{Цілі та завдання}

Розробити практичний алгоритм діагностики, комплексного лікування та профілактики пацієнтів із ХВН.

\section{Методологія}

«АнгіоЛайф венозний протокол ${ }^{\oplus}$ (далі - Протокол) ґрунтується на практичних світових рекомендаціях (настанова ESVS 2015 р., документи NICE 2015 р. та AVF 2019 р. [3-5]. Також враховано результати власних досліджень та практичного досвіду лікування пацієнтів із ХВН (застосування ендовенозної абляції та склеротерапії у пацієнтів із різними клінічними формами варикозного розширення ВНК (ВРВНК) (С1-С6), опубліковані $B$ «European Journal of Vascular and Endovascular Surgery» [11-13].

Перевагою розробленого Протоколу $\epsilon$ схематичне відображення повного «шляху» пацієнта від етапу первинного візиту (діагностики) до вибору та застосування оптимального варіанта лікування, який розділено на чотири етапи: 1) первинний візит, 2) комплексне лікування, 3) естетична корекція у разі потреби та 4) профілактика рецидивів. Крім того, відзначено переваги ранньої ендовенозної корекції у разі трофічних виразок, що підтверджено результатами як наших досліджень, так і рандомізованого дослідження EVRA (Early Venous Reflux Ablation) trial (2018), результати якого не враховано в рекомендаціях ESVS та NICE. Також роз- 
роблено методи профілактики ускладнень після склеротерапії, які відсутні в міжнародних клінічних рекомендаціях [3-5, 11-14]. Ці дані можуть дуже істотно вплинути на клінічну практику флеболога та мають бути враховані в його роботі, оскільки дають змогу значно прискорити реабілітацію пацієнтів із тяжкими проявами ХВН (зокрема з трофічними виразками) та запобігти виникненню ускладнень у хворих, яким проведено склеротерапію.

\section{Модель пацієнта}

Пацієнт із ВРВНК та клінічними проявами XBH COsС6 за класифікацією СЕАР.

\section{Протокол та алгоритми}

Менеджмент пацієнта з ХВН представлено у вигляді Протоколу - набору чітких практичних рекомендацій для судинного хірурга та флеболога, який публікується вперше*.

Протокол розроблено на підставі власного практичного досвіду, існуючих протоколів та настанов щодо лікування пацієнтів із ХВН. Протокол передбачає 4 етапи комплексу медичних заходів (рис. 1), метою якого $\epsilon$ формування чіткої програми подальшого обстеження та лікування хворого. Схематичне відображення етапів лікування $\epsilon$ власною розробкою лікарів Судинного центру «АнгіоЛайф».

Рисунок 1 Скорочена схема Протоколу та основні етапи менеджменту пацієнта з XBH

\section{АнгіоЛайф венозний протокол}

\begin{tabular}{|c|c|c|c|c|c|c|}
\hline $\begin{array}{c}\text { Діагностика } \\
\text { основної } \\
\text { проблеми }\end{array}$ & $\rightarrow$ & $\begin{array}{c}\text { Комплексне } \\
\text { лікування } \\
\text { захворювання }\end{array}$ & $\rightarrow$ & $\begin{array}{c}\text { «Естетичні } \\
\text { штрихи» }\end{array}$ & $\rightarrow$ & $\begin{array}{c}\text { Профілактика } \\
\text { майбутніх } \\
\text { рецидивів } \\
\text { захворювання }\end{array}$ \\
\hline
\end{tabular}

\section{1-й етап}

Діагностика основної проблеми передбачає опитування пацієнта і комплексне обстеження з бажаним виконанням таких етапів:

- заперечення кістково-м'язових і неврологічних захворювань;

- заперечення венозної патології органів малого таза;

- УзДС ВНК (анатомічне та гемодинамічне дослідження);

- встановлення діагнозу 3 детальною характеристикою за класифікацією СЕАР та оцінкою клінічної тяжкості захворювання за шкалою VCSS;

- оцінка якості життя пацієнта до початку лікування з використанням шкали CIVIQ-20 [24];

- визначення чинників ризику у пацієнта, який $\epsilon$ кандидатом для лікування.

Для заперечення супутніх захворювань, що можуть спричинити схожу симптоматику з венозними захворюваннями, пацієнту слід поставити запитання, наведені в таблиці, розробленій на основі класифікації Symptoms-Varices-Pathophysiology (SVP) тазового венозного розладу (2021) [15]. За наявності симптомів необхідне подальше обстеження та лікування ймовірних захворювань.

Таблиця Запитання для заперечення супутніх захворювань, що можуть спричинити схожу симптоматику з венозними захворюваннями

\begin{tabular}{|c|c|}
\hline $\begin{array}{l}\text { Заперечення кістково-м'язових } \\
\text { та неврологічних захворювань }\end{array}$ & $\begin{array}{c}\text { Заперечення венозної патології } \\
\text { в малому тазі }\end{array}$ \\
\hline \multicolumn{2}{|c|}{ Чи були за останні 6 міс: } \\
\hline $\begin{array}{l}\text { - Хронічний біль у спині } \\
\text { • Гострий біль у спині, що іррадіював у нижні } \\
\text { кінцівки } \\
\text { - Біль у суглобах (колінних, кульшових чи } \\
\text { гомілково-стопних) } \\
\text { - Судоми в нижніх кінцівках } \\
\text { - Парестезії (відчуття повзання мурашок) } \\
\text { - Відчуття печіння та інші неспецифічні відчуття }\end{array}$ & $\begin{array}{l}\text { • Хронічний тазовий біль } \\
\text { • Диспареунія (біль під час статевого акту) } \\
\text { • Дизурія (порушення нормального } \\
\text { виділення сечі) } \\
\text { • Дисменорея (виражений біль внизу } \\
\text { живота під час менструації) } \\
\text { • Посткоїтальний біль } \\
\text { - Депресія }\end{array}$ \\
\hline
\end{tabular}

*Повний алгоритм можна завантажити на сайті www.angiolife.com.иа в розділі «Для лікарів».
Для верифікації діагнозу та планування лікування пацієнтів із ХВН обов'язково проводять УзДС.

Протокол УЗДС ВНК, розроблений на основі консенсусного документу International Union of Phlebology, передбачає [16]:

1. Дослідження глибоких вен: візуалізація супраінгвінального венозного сегмента (нижньої порожнистої вени і вен здухвинного сегмента з використанням конвексного датчика 3-5 МГц). Посегментно проводять оцінку стану нижньої порожнистої вени, вен таза, загальної та зовнішньої клубових вен. Пацієнт лежить на спині (у разі підозри на тромбоз глибоких вен). За наявності тромбозу слід указати локалізацію тромбу, його протяжність, ехогенність, структуру та проксимальний кінець (якщо візуалізується). Важливо оцінити ступінь реканалізації або облітерацію просвіту при посттромботичному синдромі (ПТС). Для оцінки функції венозних клапанів та виявлення рефлюксу дослідження проводять у положенні стоячи з використанням проби Вальсальви.

2. Візуалізація інфраінгвінального венозного сегмента 3 використанням лінійного датчика 3 діапазоном частот 5-12 МГц. Посегментно проводять оцінку стану загальної стегнової, поверхневої і глибокої стегнових, підколінної, задньопередньо-великогомілкової, малогомілкової вен, м'язововенозних синусів (суральних вен) стегна та гомілки. Хворий перебуває у положенні стоячи. Виконують мануальну компресію датчиком глибоких вен для точної оцінки частки облітерації просвіту тромботичними масами. У разі неможливості пацієнта підтримувати вертикальне положення дослідження проводять у положенні лежачи. Для оцінки функції венозних клапанів та виявлення рефлюксу використовують пробу Вальсальви в загальній стегновій і поверхневій стегновій вені та проби з компресією дистальних венозних сегментів. Тривалість рефлюксу вимірюють за ретроградною хвилею кровотоку, зареєстрованого за досліджуваним клапаном у режимі кольорового та імпульсного допплера, під час проведення проби Вальсальви (в стегновому сегменті) та проб з дистальною і проксимальною компресією в дистальних венозних сегментах. Рефлюкс тривалістю <1 с (у загальній стегновій і підколінній венах) або <0,5 с в інших інфраінгвінальних венах вважають фізіологічним, він виникає за рахунок ретроградного потоку крові до того, як клапан встигає закритися. Рефлюкс в перфорантній вені вважають патологічним при тривалості >0,5 с.

3. Дослідження поверхневих вен: візуалізація сафенофеморального співустя з обох боків з оцінкою наявності рефлюксу під час проведення проби Вальсальви в режимі кольорового та імпульсного допплера.

4. Виявляють джерела атипового рефлюксу (пудендальні, епігастральні вени). Спроможність термінального та претермінального клапанів визначають окремо. Велику підшкірну вену (ВПВ) візуалізують на всій протяжності, оцінку рефлюксу проводять у нижній $1 / 3$ стегна та на гомілці, особливо в звичних місцях атипового рефлюксу з перфорантних вен (Гунтера, Додда, Шермана, Кокетта) і міжсафенних вен на гомілці (перетік із системи малої підшкірної вени (МПВ) у разі неспроможності останньої) 3 проведенням проби з дистальною компресією. Виконують пробу з компресією вени датчиком у разі клінічної підозри на тромбофлебіт або за наявності посттромботичних змін у просвіті ВПВ (наслідків раніше перенесеного флебіту).

5. Візуалізація сафено-поплітеального співустя з обох боків 3 оцінкою наявності рефлюксу під час проведення проби з дистальною компресією. Виявляють джерела атипового рефлюксу (вена Тьєрі, краніальне продовження МПВ, вена Джакоміні, сідничний перфорант). МПВ візуалізують на всій протяжності, оцінку рефлюксу проводять у середній та нижній $1 / 3$ гомілки, особливо в типових місцях атипового рефлюксу з перфорантних вен і міжсафенних вен (перетік із системи ВПВ у разі неспроможності останньої) 3 проведенням проби з дистальною компресією. Виконують пробу з компресією вени датчиком у разі клінічної підозри на тромбофлебіт або за наяв- 
ності посттромботичних змін у просвіті МПВ (наслідків раніше перенесеного флебіту).

6. Візуалізують додаткові вени на стегні (задня додаткова вена стегна, передня додаткова вена стегна), вена Леонардо та передня додаткова вена на гомілці, оцінюють наявність рефлюксу з проведенням проби з дистальною компресією. Виконують пробу з компресією вени датчиком у разі клінічної підозри на тромбофлебіт або за наявності посттромботичних змін у просвіті приток ВПВ (наслідків раніше перенесеного флебіту). Візуалізують можливі атипові джерела рефлюксу, такі як ембріональні вени, що персистують (латеральна маргінальна вена Сервеля та вена сідничного нерва), виконують оцінку рефлюксу з проведенням проби з дистальною компресією.

За наявності у пацієнта тромбозу глибоких вен, ПТС, тромбофлебіту або ВРВНК бажано провести оцінку та відобразити в протоколі ультразвукового дослідження деякі показники, наведені в алгоритмі УЗДС, оскільки саме ці чинники відіграють важливу роль у виборі тактики та оцінці ефективності лікування (рис. 2).

Рисунок 2 Алгоритм проведення УзДС ВНК при виявленні патолоriï [16]

\begin{tabular}{|c|c|c|c|}
\hline \multicolumn{4}{|c|}{ Пацієнт } \\
\hline \multicolumn{2}{|c|}{$\downarrow$} & \multicolumn{2}{|c|}{$\downarrow$} \\
\hline \multicolumn{2}{|c|}{ Глибокі вени } & \multicolumn{2}{|c|}{ Поверхневі вени } \\
\hline$\downarrow$ & $\downarrow$ & $\downarrow$ & $\downarrow$ \\
\hline $\begin{array}{c}\text { Тромбоз глибоких } \\
\text { вен }\end{array}$ & ПТС & Тромбофлебіт & Варикоз \\
\hline$\downarrow$ & $\downarrow$ & $\downarrow$ & $\downarrow$ \\
\hline $\begin{array}{l}\text { • Оцінка } \\
\text { протяжності } \\
\text { тромбозу } \\
\text { (проксимальний } \\
\text { та дистальний } \\
\text { кінець) } \\
\text { • Оцінка } \\
\text { проксимальної } \\
\text { частини тромбу } \\
\text { на предмет } \\
\text { флотації }\end{array}$ & $\begin{array}{l}\text { • Оклюзивна чи } \\
\text { неоклюзивна } \\
\text { форма } \\
\text { • Оцінка } \\
\text { протяжності зони } \\
\text { венозної оклюзії } \\
\text { • Оцінка швидкості } \\
\text { венозного } \\
\text { рефлюксу }\end{array}$ & $\begin{array}{l}\text { • Оцінка } \\
\text { протяжності } \\
\text { тромбозу } \\
\text { (проксимальний } \\
\text { та дистальний } \\
\text { кінець) } \\
\text { • Оцінка глибоких } \\
\text { вен (заперечення } \\
\text { трансфасціально- } \\
\text { го тромбозу) }\end{array}$ & $\begin{array}{l}\text { • Оцінка рефлюксу } \\
\text { із зазначенням } \\
\text { основних точок } \\
\text { венозного скиду } \\
\text { • Заперечення } \\
\text { патології } \\
\text { глибоких вен }\end{array}$ \\
\hline
\end{tabular}

Завершенням 1-го етапу $\epsilon$ формування основного діагнозу з класифікацією ХВН за СЕAР та оцінкою клінічної тяжкості захворювання за шкалою VCSS. На цьому етапі слід оцінити якість життя пацієнтів із використанням опитувальника CIVIQ-20, як зазначено в європейських клінічних рекомендаціgх $[3,4]$.

Важливо надати пацієнтам із ХВН інформацію, зокрема пояснити, що таке ХВН, можливі причиниії̈виникнення та ймовірність прогресування, можливі ускладнення (тромбоз глибоких вен, зміни шкіри, трофічні зміни, кровотечі та варикотромбофлебіт). Необхідно спростувати стереотипи та будь-які хибні уявлення про ризик розвитку ускладнень у пацієнта.

\section{2-й етап}

Комплексне лікування захворювання. На цьому етапі важливе значення має повне залучення пацієнта у лікування та вибір оптимального комплексу лікувальних процедур:

- флеботропні препарати;

- сертифікований флебологічний трикотаж;

- ендовенозна лазерна коагуляція (EVLA, EVLT);

- радіохвильова облітерація (RFA, EVRF);

- адгезивна клейова облітерація (VenaBLOCK, VenaSeal);

- механохімічна облітерація (Flebogrif, Clarivein);

- склеротерапія (ехосклеротерапія, трансілюмінаційна склеротерапія).

Ефективність кожного методу лікування підтверджена результатами десятків клінічних досліджень та рекомендована європейськими і американськими клінічними настановами [3-5].
Флеботропні препарати (діосмін 600 мг, сулодексид)

Флеботропні препарати - клас препаратів, представлений рослинними флавоноїдами, напівсинтетичними та синтетичними сполуками. Перевагу слід надавати оригінальним препаратам діосмінового ряду. Вони мають значну доказову базу щодо зменшення вираженості такого симптому ХВН, як набряк кінцівки (С3), і зменшують час загоєння трофічних виразок (C6). Крім того, ця група препаратів має вищу ефективність порівняно з плацебо щодо зменшення вираженості трофічних розладів (C4+) і таких суб'єктивних симптомів, як судоми, синдром неспокійних ніг і парестезія [4]. Цей ефект пояснюється мультифункціональним впливом на судинну стінку та клапанний апарат, переважно зниженням ролінгу лейкоцитів та активності запалення.

\section{Сертифікований флебологічний трикотаж}

Компресійна терапія залишається основним методом консервативного лікування пацієнтів із ХВН. ІІї перевагами $\epsilon$ зручність використання, неінвазивний характер та ефективність впливу на венозну гіпертензію як основний патофізіологічний механізм венозної недостатності. Найпоширеніші форми терапевтичної компресії - медичний трикотаж (панчохи, гольфи, колготи), нееластичні та еластичні бандажі, переривчасте пневматичне стиснення. Механізм дії полягає у тиску на глибокі вени і поліпшенні функції м'язової помпи, що сприяє зниженню венозного тиску та набряків (Management of Chronic Venous Disease Clinical Practice Guidelines, ESVS 2015 p.) [4].

Згідно з настановою ESVS 2015 р. компресійна терапія рекомендована як ефективний метод терапії для зменшення вираженості симптомів і проявів ХВН нижніх кінцівок. Рекомендоване використання тимчасової компресійної терапії для пацієнтів із XВН, які проводитимуть інвазивне лікування. Також цей метод використовують для лікування пацієнтів, в яких недоцільно застосовувати інвазивні методи терапії. Після медичних втручань на венах кінцівок рекомендоване використання еластичної компресії.

\section{Лікувальний алгоритм пачієнта з ВРВНК}

Для вибору оптимального методу лікування пропонуємо такий лікувальний алгоритм. При стадії С1 за СЕАР та відсутності рефлюксу в системі підшкірних вен рекомендоване використання мікросклеротерапії або кріосклеротерапії, у разі сафенового рефлюксу тривалістю <1 с - як 1-й етап виконують черезшкірну вальвулопластику гіалуроновою кислотою (ЧШВГК), 2-й мікросклеротерапія або кріосклеротерапія (рис. 3). Методика розроблена J.C. Ragg і представлена на Європейському конгресі з радіологіï (European Congress of Radiology - ECR) у 2019 р. [17], а модифікацію методики для короткого рефлюксу (0,5-1,0 c) розробили лікарі Судинного центру «АнгіоЛайф».

Рисунок 3 Методика проведення ЧШВГК (модифікація лікарів Судинного центру «АнгіоЛайф»)
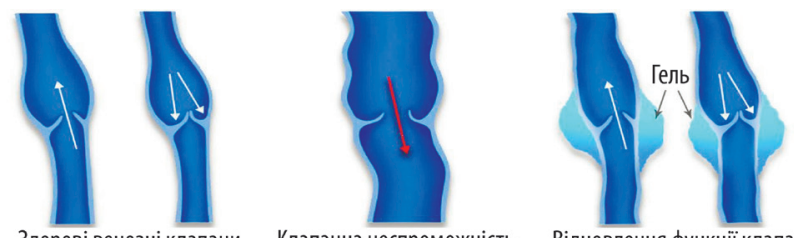

Здорові венозні клапани Клапанна неспроможність Відновлення функції клапана правильний венозний відтік венозний рефлюкс (0,5-1 с) відновлення венозного відтоку

Використання ЧШВГК при частковій клапанній неспроможності дає змогу достовірно поліпшити венозний відтік і знизити ризик утворення гіперпігментацій після склеротерапії. За нашими даними, після проведення 1-го сеансу ЧШВГК відновлена функція сафенового клапана зберігається мінімум протягом 1 року.

Якщо у пацієнта верифіковано неспроможність ВПВ або МПВ з тривалістю рефлюкса >1 с і стадію XBH COsC6 за CEAP при діаметрі ураженої вени <11 мм, бажано використати нетермальну адгезивну облітерацію (біоклей) або термічні методи облітерації (ендовенозної лазерної коагуля- 
ції або радіохвильової абляції). Якщо діаметр вени становить $>11$ мм, рекомендоване проведення ендовенозної лазерної коагуляції або радіохвильової абляції. Це відповідає міжнародним клінічним рекомендаціям [3-5].

Якщо у пацієнта діагностовано ізольовану неспроможність перфорантних вен та варикозних приток з довжиною рівного сегмента $>10 \mathrm{~cm}$, бажано виконати термальну абляцію проксимальних сегментів з мікрофлебектомією уражених вариксів або провести етапну ехосклеротерапію. Якщо довжина рівного сегмента варикозного витоку $<10 \mathrm{~cm}$ та уражені перфоранти Гунтера, Кокетта, Тьєрі тощо, бажано проведення етапної ехосклеротерапії або мікрофлебектомії уражених вен (рис. 4).

При виявленні вторинного варикозного захворювання підшкірних вен унаслідок ураження системи глибоких вен бажано проведення мультиспіральної комп'ютерної томографії або магнітно-резонансної томографії - флебографії і мультидисциплінарний підхід до лікування.

\section{Алгоритм лікування хворого}

із постттомботичною хворобою

Пацієнту з ПТС, у якого при УЗДС виявлено рефлюкс у глибоких венах тривалістю >1 с, рекомендоване комплексне консервативне лікування (сулодексид, флеботонічні препарати та компресійна терапія). Сулодексид пригнічує Ха-фактор згортання крові та має ендотелійпротекторні властивості. Контрольний огляд пацієнта проводять через 1 рік. Пацієнтам із рефлюксом глибоких вен нижньої кінцівки тривалістю <1 с і варикозною трансформацією підшкірних вен рекомендоване виконання абляції магістральних поверхневих вен та приток. Таким чином, знижуються венозна гіпертензія і прояви ХВН.

Тактика лікування обструктивної форми ПТС залежить від розташування післятромботичної оклюзії (рис. 5). При супраінгвінальному розташуванні венозної оклюзії глибоких вен, клінічно значущому перебігу ХВН (C4+) і відсутності ефекту від консервативного лікування бажано розглянути можливість ендоваскулярної реканалізації та стентування здухвинного сегмента.
При обструкції нижче за клубову зв'язку і трофічні виразки рекомендоване виконання облітерації неспроможних перфорантних вен та варикозних приток ВПВ або МПВ додатково до комплексної консервативної терапії.

При обговоренні з пацієнтом етапів лікування ВРВНК обов'язково слід поінформувати, які варіанти лікування доступні, переваги і ризики кожного варіанта. Слід пояснити, що у разі недотримання рекомендацій щодо профілактики нова варикозна трансформація може з'явитися швидше. Зазвичай потрібно більше одного сеансу лікування для досягнення очікуваного функціонального та косметичного ефекту. Частота виникнення рецидивних вен після повторного лікування вища, ніж після першого.

\section{3-й етап}

Для досягнення хорошого косметичного ефекту лікування застосовують:

- мікросклеротерапію (кріосклеротерапію);

- CLACS (кріолазер-кріосклеротерапію);

- транскутанний YAG-лазер;

- консервативне лікування.

\section{Алгоритм проведення склеротерапії}

Склеротерапія $\epsilon$ незамінним методом лікування пацієнтів із ВРВНК, оскільки її можна використовувати для лікування клапанної неспроможності підшкірних чи перфорантних вен (особливо у пацієнтів із рецидивами захворювання), а також для досягнення оптимальних косметичних результатів лікування при будь-якому варіанті клінічної форми (С1-С6). Однак помилки при виконанні процедури можуть мати серйозні наслідки i тяжкі ускладнення: від некрозу шкіри та м'яких тканин до тромбозу глибоких вен і тромбоемболії легеневої артерії. Тому коректне технічне виконання процедури є запорукою прогнозованого результату з мінімальним ризиком побічної дії.

Перед використанням склеротерапії слід розглянути питання щодо усунення аксіального рефлюксу, як описано вище. Foam-Form (пінна форма склерозанта) склеротерапія $\epsilon$ методом вибору при етапному усуненні приток підшкірних

Рисунок 4 Алгоритм лікування пацієнта із BPBHК залежно від типу ураження поверхневих вен (на підставі рекомендацій ESVS та доповнено з урахуванням нових даних щодо ефективності методів нетермічної абляції $[4,18]$

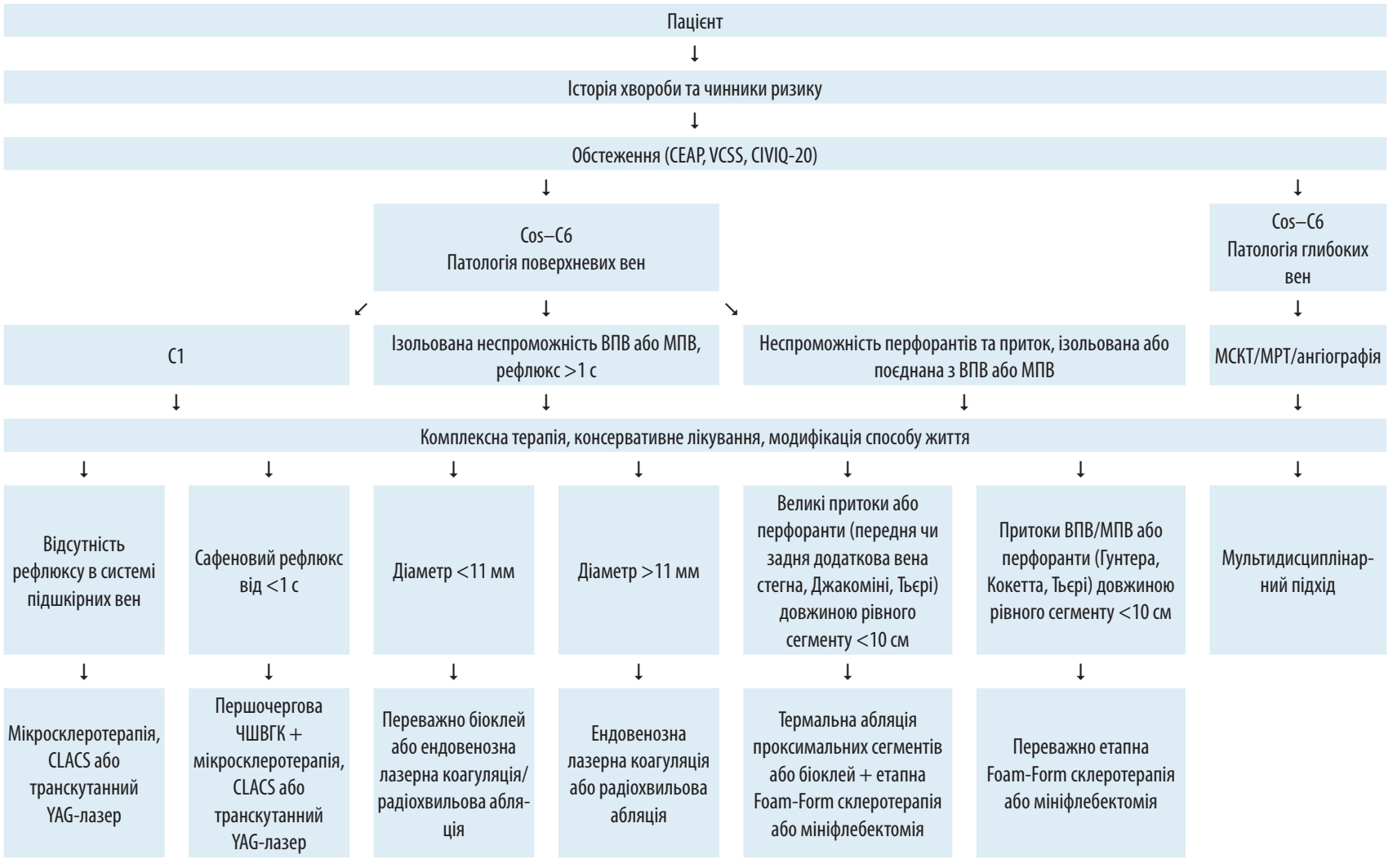


Рисунок 5 Алгоритм лікування пацієнта із ПТС (на основі практичних рекомендацій, опублікованих в «Journal of Thrombosis and Thrombolysis», а також Cochrane Database of Systematic Reviews [19, 20])

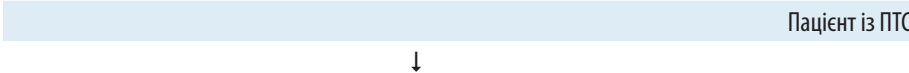

Рефлюкс-форма в будь-якому сегменті глибоких вен $\downarrow$
Рефлюкс >1c

$\downarrow$

- Сулодексид
- Флеботонічні препарати
- Компресійна терапія
- Контроль УздС через 1 рік

- Сулодексид

- Компресійна терапія

- Контроль УзДС через 1 рік

\section{$\downarrow$}

Рефлюкс $<1$ с

$\downarrow$

Можливе виконання абляції магістральних підшкірних вен та їх приток (у разі наявності значущого рефлюксу та клінічних симптомів (2+)

$$
\downarrow
$$

Компресійна терапія для резидуального глибокого венозного рефлюксу вен після ендовенозного лікування. Мінімальний термін після ендовенозного втручання становить 1 міс, оскільки значна частка приток значно зменшується після усунення джерела венозної гіпертензії. Лише у разі клінічної форми С6 можна розглянути склеротерапію субдермального перивенозного сплетіння в більш ранні терміни, оскільки ця процедура може пришвидшити час загоєння виразки. Для лікування приток слід використовувати Foam-Form 1,0-1,5\% розчин етоксисклеролу і катетер з голкою 25G. Для лікування перфорантних вен можна розглянути вищу концентрацію розчину (до 3,0\%) та використовувати катетер з голкою 23-25G.

Для лікування клінічної форми С1 обов'язково слід дотримуватися таких правил: рухатися у дистальному напрямі та першим етапом склерозувати ретикулярні вени $(0,50-0,75 \%$ розчин етоксисклеролу, катетер з голкою 27G). Для лікування телеангіектазій краще застосовувати рідкий 0,25-0,33\% розчин етоксисклеролу, обов'язково використовувати оптичне збільшення та додаткове освітлення, працювати голкою 31-33G, залежно від діаметра телеангіектазій (рис. 6).

Компресійну терапію застосовують упродовж щонайменше 2 тиж (краще - протягом декількох місяців), оскільки вона поліпшує віддалені результати та знижує частоту гіперпігментацій. У разі появи останніх можна розглянути використання сулодексиду в дозі $250 \mathrm{MO}$ двічі на добу протягом 2 міс та мікрокоагулектомій (дренування постсклеротичних коагул) не раніше ніж через 2 тиж після процедури.

Якщо не вдалося досягти технічного результату (закрити просвіт цільової вени), слід розглянути підвищення концентрації на 0,25-0,50\% порівняно з останнім сеансом склеротерапії. При лікуванні телеангіектазій і залишкових гіперпігментацій можливе використання транскутанного лазера $(\lambda=1064$ нм) Nd YAG.

Важливо дотримуватися таких правил:

- не використовувати >10 мл пінного розчину за 1 сеанс склеротерапії;

- за одну ін'єкцію небажано вводити >2 мл пінного чи рідкого розчину (лікування приток) та >0,5 мл (ретикулярні вени i телеангіектазії);

- максимально допустима доза введеного етоксисклеролу за один сеанс лікування - 2 мг/кг маси тіла.

Дотримання зазначених правил дає змогу мінімізувати ризик ускладнень та досягти хороших естетичних результатів лікування.

\section{4-й етап}

Профілактика майбутніх рецидивів захворювання та контроль ефективності лікування полягають у детальному поясненні пацієнту важливості профілактичних заходів:

- модифікація способу життя (здоровий спосіб життя, регулярні фізичні вправи, здорове харчування); $\downarrow$

Обструктивна форма в будь-якому сегменті глибоких вен

\begin{tabular}{|c|c|}
\hline$\downarrow$ & $\downarrow$ \\
\hline $\begin{array}{l}\text { Інфраінгвінальний сегмент } \\
\text { (підколінна чи стегнова вена) }\end{array}$ & $\begin{array}{l}\text { Супраінгвінальний сегмент } \\
\text { (здухвинні вени) }\end{array}$ \\
\hline$\downarrow$ & $\downarrow$ \\
\hline $\begin{array}{l}\text { - Сулодексид } \\
\text { - Флеботонічні препарати } \\
\text { - Компресійна терапія } \\
\text { - Контроль УзДС через } 1 \text { рік }\end{array}$ & $\begin{array}{l}\text { - Сулодексид } \\
\text { - Флеботонічні препарати } \\
\text { - Компресійна терапія } \\
\text { - Контроль УЗДС через } 1 \text { рік }\end{array}$ \\
\hline$\downarrow$ & $\downarrow$ \\
\hline $\begin{array}{c}\text { Можливе лікування неспроможних } \\
\text { приток ВПВ чи МПВ на гомілці у разі С6 } \\
\text { (склеротерапія) при недостатній } \\
\text { ефективності компресії }\end{array}$ & $\begin{array}{c}\text { У разі неефективності та С4+ } \\
\text { розглянути можливість стентування } \\
\text { здухвинних вен }\end{array}$ \\
\hline
\end{tabular}

- зменшення чинників ризику (статичні навантаження, знерухомлення, гормональна терапія);

- контроль якості життя пацієнта після лікування з використанням опитувальника CIVIQ-20;

- регулярні профілактичні огляди та УзДС судинної системи 1 раз на рік.

Модифікація способу життя для пацієнтів із ХВН, особливо з тяжкими формами ПТС, чинить значущий вплив на результат комплексного лікування. Дуже важливо пояснити пацієнту обмеження звичок, які негативно впливають на перебіг XВН: зменшити статичні навантаження, не сидіти, склавши нога на ногу. При сидячій роботі щогодини робити 5-хвилинні розминки. Не носити вузьке взуття на високих підборах, перевзуватися на роботі в зручне взуття з невисоким підйомом. Обов'язково слід відмовитися від тютюнопаління, оскільки нікотин негативно впливає на ендотелій судин.

Важливою ціллю $\epsilon$ об'єктивізація результатів лікування, переважно за рахунок поліпшення якості життя пацієнта з ХВН. Для цього слід провести контрольне опитування через 6-12 міс після лікування (наприклад з використанням опитувальника CIVIQ-20, який $\epsilon$ дуже зручним інструментом) та порівняти результати з вихідними. Крім того, пацієнти обов'язково мають проходити регулярні профілактичні огляди (щонайменше 1 раз на рік), оновлювати компресійний трикотаж, дотримуватися правил модифікації способу життя. Контрольні ультразвукові дослідження дадуть змогу виявити прогресування захворювання і рецидиви на ранніх стадіях та виконати малотравматичні втручання.

\section{Критерії оцінки ефективності лікування}

Головними критеріями, яким має бути приділена основна увага лікаря, $\epsilon$ оцінка до лікування і контроль у динаміці лікування такого показника, як якість життя пацієнта. Для цього можна використати валідний опитувальник CIVIQ-20. Крім того, лікар і пацієнт повинні оцінити оптимальність та задоволеність отриманим функціональним і косметичним результатом. Важливе значення має також оцінка віддалених результатів, зокрема частоти рецидиву ВРВНК та проявів ХВН. Використання запропонованого алгоритму дає змогу розробити чітку програму діагностичних та лікувальних заходів і спрогнозувати результат лікування для пацієнта з ХВН.

\section{Фінансування}

Фінансування за власні кошти авторів.

\section{Внесок авторів}

О.М. Волошин, О.В. Суздаленко - ідея, концепція і дизайн дослідження; С.М. Мачуський, О.Г. Попова, О.М. Волошин, О.В. Суздаленко, В.О. Губка - збір та аналіз отриманих результатів; О.В. Суздаленко, С.М. Мачуський, В.Д. Павліченко, О.Г. Попова, С.Т. Расул-заде - редагування та написання тексту. 
Рисунок 6 Алгоритм проведення склеротерапії залежно від діаметра варикозних вен (на основі European Guidelines for Sclerotherapy in Chronic Venous Disorders, а також результатів власних досліджень з профілактики гіперпігментацій, опублікованих в «European Journal of Vascular and Endovascular Surgery» $[13,21])$

\begin{tabular}{|c|c|c|c|c|}
\hline \multicolumn{5}{|c|}{ Пацієнт } \\
\hline \multicolumn{5}{|c|}{$\downarrow$} \\
\hline \multicolumn{5}{|c|}{ Історія хвороби, чинник ризику та УЗДС } \\
\hline \multicolumn{5}{|c|}{$\downarrow$} \\
\hline \multicolumn{5}{|c|}{$\begin{array}{c}\text { Лікування аксіального рефлюксу ВПВ чи МПВ з використанням термальних чи нетермальних методів абляції + мініфлебектомії (роз'єднання проксимальних точок рефлюксу великих } \\
\text { притоків) }\end{array}$} \\
\hline \multirow{4}{*}{$\begin{array}{c}\downarrow \\
\text { Залишкові притоки на гомілці та } \\
\text { стегні (бажано втручання через } \\
1 \text { міс після процедури) - C2-С6 } \\
\text { (у разі (6 розглянути } \\
\text { склеротерапію субдермального } \\
\text { венозного сплетіння на } \\
\text { наступний день після } \\
\text { ендовенозної корекції) }\end{array}$} & $\downarrow$ & & & $\downarrow$ \\
\hline & \multirow[b]{3}{*}{$\begin{array}{c}\text { Залишкові перфоранти на } \\
\text { гомілці діаметром <0,35 см } \\
\text { і рефлюксом <0,35 с (С4-С6) } \\
\text { після лікування аксіального } \\
\text { рефлюксу }\end{array}$} & Ретикуль & вени (С1) & Телеангіектазії (С1) \\
\hline & & & & $\downarrow$ \\
\hline & & \multicolumn{3}{|c|}{$\begin{array}{l}\text { Лікування у дистальному напрямі, спочатку ретикулярні вени, потім телеангіектазії. Можна одномоментно, } \\
\text { якщо ретикуляр живить телеангіектазії }\end{array}$} \\
\hline$\downarrow$ & $\downarrow$ & $\downarrow$ & $\downarrow$ & $\downarrow$ \\
\hline $\begin{array}{l}\text { Foam-Form склеротерапія } \\
\text { 1-1,5\% розчином етоксисклеро- } \\
\text { лу катетером } 25 \text { з з використан- } \\
\text { ням Veinlite aбo Veinviewer }\end{array}$ & $\begin{array}{l}\text { Ехоконтрольована Foam-Form } \\
\text { склеротерапія 1,5-3\% розчином } \\
\text { етоксисклеролу катетером } 25 \mathrm{G}\end{array}$ & $\begin{array}{c}\text { Великий діаметр 3-4 мм - } \\
\text { пінна склеротерапія 0,5-0,75\% } \\
\text { розчином етоксисклеролу } \\
\text { (глюкоза 70\% у якості } \\
\text { розчинника) катетером 25G } \\
\text { з використанням Veinlite a60 } \\
\text { Veinviewer }\end{array}$ & $\begin{array}{c}\text { Малий діаметр 1-2 мм — скле- } \\
\text { ротерапія 0,33-0,5\% рідким } \\
\text { розчином етоксисклеролу } \\
\text { (глюкоза 70\% у якості } \\
\text { розчинника) або 0,33\% } \\
\text { Foam-Form катетером 27G } 3 \\
\text { використанням Veinlite }\end{array}$ & $\begin{array}{c}\text { Мікросклеротерапія 0,2-0,33\% } \\
\text { рідким розчином етоксисклеро- } \\
\text { лу (глюкоза 70\% у якості } \\
\text { розчинника) з використанням } \\
\text { оптичного збільшення та голки } \\
27 G-31 G\end{array}$ \\
\hline
\end{tabular}

Компресійна терапія мінімум 2 тиж (краще 2 міс). У разі гіперпігментацій — сулодексид 1 капс. 2 рази на добу 2 міс + розглянути можливість мікрокоагулоектомії з використанням голки 18G через $\geq 2$ тиж

У разі неефективності чи недостатнього ефекту збільшити концентрацію склерозанта на 1 порядок (на 0,25-0,5\%)

У разі неефективності чи недостатнього ефекту — р03глянути використання транскутанного лазера

\section{Конфлікт інтересів}

Автори, які взяли участь у цьому дослідженні, заявили, що не мають конфлікту інтересів щодо даного рукопису.

\section{Згода на публікацію}

Всі автори прочитали і схвалили остаточний варіант рукопису та дали свою згоду на публікацію.

\section{Список використаної літератури}

1. McArdle M., Hernandez-Vila E.A. (2017) Management of chronic venous disease. Texas Heart Institute J., 44(5): 347-349.

2. Belramman A., Bootun R., Lane T.R., Davies A.H. (2019) Endovenous management of varicose veins. Angiology, 70(5): 388-396.

3. Wittens C., Davies A.H., Bækgaard N. et al.; ESVS Guidelines Committee (2015) Editor's choice-management of chronic venous disease: clinical practice guidelines of the European Society for Vascular Surgery (ESVS). Eur. J. Vasc. Endovasc. Surg., 49(6): 678-737.

4. Carradice D., Forsyth J., Mohammed A. et al. (2018) Compliance with NICE guidelines when commissioning varicose vein procedures. BJS Open, 2(6): 419-425.

5. Lurie F., Lal B.K., Antignani P.L. et al. (2019) Compression therapy after invasive treatment of superficial veins of the lower extremities: Clinical practice guidelines of the American Venous Forum, Society for Vascular Surgery, American College of Phlebology, Society for Vascular Medicine, and International Union of Phlebology. J. Vasc. Surg. Venous Lymph. Dis., 7(1): 17-28.

6. Raetz J., Wilson M., Collins K. (2019) Varicose veins: Diagnosis and treatment. Am. Fam. Phys., 99(11): 682-688.

7. Davies A.H. (2019) The seriousness of chronic venous disease: a review of real-world evidence. Advances in Therapy, 36(1): 5-12.

8. Garcia R., Labropoulos N. (2018) Duplex ultrasound for the diagnosis of acute and chronic venous diseases. Surg. Clin., 98(2): 201-218.

9. Labropoulos N. (2019) How does chronic venous disease progress from the first symptoms to the advanced stages? A review. Advances in Therapy, 36(1): 13-19.

10. Kheirelseid E.A., Crowe G., Sehgal R. et al. (2018) Systematic review and meta-analysis of randomized controlled trials evaluating long-term outcomes of endovenous management of lower extremity varicose veins. J. Vasc. Surg. Venous Lymph. Dis., 6(2): 256-270.
11. Suzdalenko 0.V., Voloshyn 0.M. (2019) EVLT and Foam-form Sclerotherapy as a C6 Stage Varicose Treatment. Eur. J. Vasc. Endovasc. Surg., 58(6): 478-479.

12. Voloshyn 0., Suzdalenko 0. (2019) Early Versus Deferred Endovenous Superficial Venous Treatment in Patients with Varicose Trophic Ulcers. Eur. J. Vasc. Endovasc. Surg, 58(6): 843.

13. Suzdalenko 0., Voloshyn 0. (2019) Hyperpigmentation After Sclerotherapy Management. Eur. J.Vasc. Endovasc. Surg., 58(6): 843-844.

14. Gohel M. S., Heatley F., Liu X. et al. (2018) A randomized trial of early endovenous ablation in venous ulceration. New Engl. J. Med., 378(22): 2105-2114.

15. Meissner M.H., Khilnani N.M., Labropoulos N. et al. (2021) The symptoms-varices-pathophysiology classification of pelvic venous disorders: a report of the American Vein \& Lymphatic Society international working group on pelvic venous disorders. Phlebology, 36(5):342-360.

16. De Maeseneer M., Pichot 0., Cavezzi A. et al. (2011) Duplex ultrasound investigation of the veins of the lower limbs after treatment for varicose veins - UIP consensus document. Eur. J. Vasc. Endovasc. Surg., 42(1): 89-102.

17. Grünwald J., Ragg J.C. (2019) Perivascular hyaluronan-new cure for venous insufficiency. Eur. Congr. Radiol. - ECR.

18. Vos C.G., Ünlü Ç., Bosma J. et al. (2017) A systematic review and meta-analysis of two novel techniques of nonthermal endovenous ablation of the great saphenous vein. J. Vasc. Surg. Ven. Lymph. Dis., 5(6): 880-896.

19. Kahn S.R., Galanaud J.P., Vedantham S., Ginsberg J.S. (2016) Guidance for the prevention and treatment of the post-thrombotic syndrome. J. Thromb. Thrombolysis, 41(1): 144-153.

20. Azirar S., Appelen D., Prins M.H. et al. (2019) Compression therapy for treating post-thrombotic syndrome. Cochrane Database of Systematic Reviews, 9.

21. Rabe E., Breu F.X., Cavezzi A. et al.; Guideline Group (2014) European guidelines for sclerotherapy in chronic venous disorders. Phlebology, 29(6): 338-354.

22. Lurie F., Passman M., Meisner M. et al. (2020) The 2020 update of the CEAP classification system and reporting standards. J.Vasc. Surg. Venous Lymph. Dis., 8(3): 342-352.

23. Passman M.A., McLafferty R.B., Lentz M.F. et al. (2011) Validation of venous clinical severity score (VCSS) with other venous severity assessment tools from the American venous forum, national venous screening program. J. Vasc. Surg., 54(6): 2-9.

24. Launois R., Mansilha A., Jantet G. (2010) International psychometric validation of the Chronic Venous Disease quality of life Questionnaire (CIVIQ-20). Eur. J. Vasc. Endovasc. Surg., 40(6): 783-789. 


\section{Management of a patient with chronic venous insufficiency}

\section{O.M. Voloshyn, O.V. Suzdalenko, V.O. Gubka, S.M. Machuskyi, V.D. Pavlychenko, O.G. Popova, S.T. Rasul-zade}

AngioLife Vascular Center, Zaporizhzhia, Ukraine

Abstract. A lot of recommendations has been published regarding the treatment of chronic venous disease. At the same time, none of these documents reflects the complete «path» of the patient from the stage of the initial visit (diagnosis) to the choice of the optimal treatment option. Therefore, the creation of a protocol that would take into account the most modern and proven effective approaches to diagnosis and treatment, and the individual characteristics of each clinical case is an urgent task. The aim of the publication is to create

\section{Відомості про авторів:}

Волошин Олександр Миколайович — кандидат медичних наук, судинний хірург/флеболог, Судинний центр «АнгіоЛайф», Запоріжжя, Україна. ORCID: 0000-0003-3924-4005

Суздаленко Олександр Вікторович - судинний хірург/флеболог, Судинний центр «АнгіоЛайф», Запоріжжя, Україна. ORCID: 0000-0003-3924-4005

Губка Віктор Олександрович — доктор медичних наук, професор, судинний хірург/флеболог, Судинний центр «АнгіоЛайф», Запоріжжя, Україна. ORCID: 0000-0002-6912-8577

Мачуський Сергій Миколайович - судинний хірург, Судинний центр «АнгіоЛайф», Запоріжжя, Україна. ORCID: 0000-0002-0985-223Х

Павліченко Віктор Дмитрович — судинний хірург/флеболог, Судинний центр «АнгіоЛайф», Запоріжжя, Україна. ORCID: 0000-0003-4034-5321

Попова Олена Геннадіївна — лікар ультразвукової діагностики, терапевт, Судинний центр «АнгіоЛайф», Запоріжжя, Україна. ORCID: 0000-0003-4716-0258

Расул-заде Сона Тарієловна — лікар-лімфолог, Судинний центр «АнгіоЛайф», Запоріжжя, Україна. ORCID: 0000-0001-6376-6175

Адреса для кореспонденції:

Мачуський Сергій Миколайович

69063, Запоріжжя, вул. Дніпровська, 24

E-mail: Senia.334@gmail.com
}

a practice-oriented instruction for the diagnosis, comprehensive treatment and prevention of chronic venous insufficiency. The management of a patient with chronic venous insufficiency is presented in the "AngioLife Venous Protocol ${ }^{\oplus}$ », a set of clear practical recommendations for vascular surgeon and phlebologist. This protocol is based on our own practical experience, existing protocols and guidelines for the treatment of patients with chronic venous insufficiency. The protocol includes four stages of a set of medical measures, the purpose of which is to form a clear program of further examination and treatment of the patient. Adherence to all the recommendations specified in the protocol allows to obtain satisfactory functional and cosmetic results of treatment of patients with chronic venous insufficiency with minimal risk of recurrence.

Key words: varicose ailment, chronic venous insufficiency, algorithm for treating varicose veins.

\section{Information about the authors:}

Voloshyn Olexander M. - Candidate of Medical Sciences, vascular surgeon/phlebologist, AngioLife Vascular Center, Zaporizhzhia, Ukraine. ORCID: 0000-0003-3924-4005

Suzdalenko Olexander V. - vascular surgeon/phlebologist, AngioLife Vascular Center, Zaporizhzhia, Ukraine. ORCID: 0000-0003-3924-4005

Gubka Victor 0. - doctor of medical sciences, professor, vascular surgeon/phlebologist, AngioLife Vascular Center, Zaporizhzhia, Ukraine. ORCID: 0000-0002-6912-8577

Machuskyi Sergii M. - vascular surgeon, AngioLife Vascular Center, Zaporizhzhia, Ukraine. ORCID: 0000-0002-0985-223X

Pavlychenko Viktor D. — vascular surgeon/phlebologist, AngioLife Vascular Center, Zaporizhzhya, Ukraine. ORCID: 0000-0003-4034-5321

Popova Olena G. - doctor of ultrasound diagnostics, therapist, AngioLife Vascular Center, Zaporizhzhia, Ukraine. ORCID: 0000-0003-4716-0258

Rasul-zade Sona T. - lymphologist, AngioLife Vascular Center, Zaporizhzhia, Ukraine. ORCID: 0000-0001-6376-6175

Address for correspondence:

Sergii Machuskyi

69063, Zaporizhzhia, Dniprovska str., 24

E-mail:Senia.334@gmail.com 